\title{
Preparedness for Internship: A Survey of New Interns at a Tertiary Care Hospital, Telangana
}

Padmavathi $\mathbf{V}^{1}$, Kranti Tekulapally *

\author{
1 Professor and Head, Department of Pharmacology, Malla Reddy Medical College for Women, Suraram, \\ Hyderabad
}

* Corresponding author, Associate Professor, Department of Pharmacology, Malla Reddy Medical College for Women, Suraram, Hyderabad.

Address of the corresponding author:Dr. Kranti Tekulapally ,Plot No.23, Royal Gardens,Jai Jawahar Nagar, Yapral,Secunderabad - 500087. Email: dr_t_kranti@yahoo.com.

Contact No. 09866676590

DOI:10.47799/pimr.0902.06

\section{ABSTRACT}

\section{INTRODUCTION}

An internship orientation program is conducted in most of the medical colleges before the beginning of internship program to facilitate the transition between medical student and intern. The present study was initiated to assess the preparedness of interns for the internship program and identifying the areas that require additional training and education.

\section{MATERIALS AND METHODS}

A cross sectional study was carried out among 2014 batch interns of Malla Reddy Medical College for Women, Suraram, Hyderabad. Hard copies of the study questionnaire prepared and validated by expert panel was administered to the interns before and after the two-day internship orientation program. The outcomes were measured on 5-point quantitative scale. The raw scores obtained by each student were converted to percentages.The scores less than or equal to $49 \%$ were considered low, the scores between $50 \%$ to $70 \%$ were considered as average and scores above $71 \%$ were considered high with respect to level of preparedness for internship. Two open ended questions were asked - additional topics to be included in the program and other suggestions.

\section{RESULTS}

A total of 110 students completed the study. Only $2 \%$ of the interns were highly prepared for hospital practice before the orientation program while this number increased to $78 \%$ after the program. Interns expressed their desire to learn new topics like basic first aid to minor injuries, management of trauma cases and Road Traffic Accidents and handling of medical emergencies during the orientation program. They also suggested that there should more focus on practical demonstrations and hands on training in skill lab during this program.

\section{CONCLUSION}

here is significant improvement in the preparedness of interns after the orientation program indicated the program helped to boost the confidence of the interns for hospital practice.

\section{KEYWORDS:}

Internship, medical students, training Preparedness For Internship: A Survey Of New Interns At A Tertiary Care Hospital, Telangana

\section{INTRODUCTION}

Internship is a phase of training wherein a graduate is expected to conduct actual practice of medical and health care and acquire skills under supervision of a trained doctor.At the end of the internship, the graduate should be able to diagnose clinical common disease conditions encountered in practice and make timely decision for referral to higher level, use discreetly the essential drugs, infusions, blood or its substitutes and laboratory services, manage all type of emergenciesmedical, surgical, obstetric, neonatal and paediatric, by rendering first level care, demonstrate skills in monitoring of the National Health Programme and schemes, oriented to provide preventive and promotive health care services to the community, develop leadership qualities to function effectively as a leader of the health team organised to deliver the health and family welfare service in existing socioeconomic, political and cultural environment and render services to chronically sick and disabled (both physical and mental) and to communicate effectively with patient and the community. ${ }^{1}$

Interns are stressed by the demands put forward by the busy working schedule and hospital environment right from day one of their internship program. The root cause of their stress being in the ability to demonstrate the skills that they are not actually taught in the medical schools like prioritization 
of clinical tasks, need to make timely decisions, maintain effective communication with the seniors, peers, ward staff and even patients.

A student thus requires attaining a range of skills and attributes to become an intern. To facilitate this smooth transition, an Internship orientation program is usually conducted in all the medical colleges before the beginning of internship. The objectives of this internship orientation program are to enable the interns to (i) appreciate the need for developing good communication skills for better doctorpatient interactions; (ii) assess the psychosocial needs of patients while providing patient care; (iii) identify the ethical and medico-legal issues involved in patient care; (iv) enhance their communication skills; ( $v$ ) appreciate the principles of rational drug therapy; (vi) familiarize themselves with universal precautions and biomedical waste management; (vii) develop and refine the skills of writing requisitions for investigations and collection and transport of samples for effective use of laboratory services; (viii) identify their role in a multidisciplinary team; and (ix) develop a sense of belonging, responsibility and accountability. ${ }^{2}$

There are limited reports from Telangana on the effectiveness of an orientation program in the preparation of students for their Internship. The present study was initiated with the objective of assessing the work preparedness of interns and identifying the areas that require for further training and education. It is often used as a tool to assess and audit the performance

\section{MATERIALS AND METHODS}

A cross sectional study was carried out among the 2014 batch interns of Malla Reddy Medical College for Women, Suraram, Hyderabad, Telangana. A self-assessment survey tool consisting of 15 items was developed by the researchers and validated by expert panel to be used in the present study. The questionnaire was administered to the interns before and at the end of two-day Internship orientation program held in March 2019. Sufficient time was given to the students to complete the questionnaire. The data obtained from the completed questionnaires were entered into Microsoft excel and descriptive statistics were calculated for overall sample. For the first 13 questions, five-point quantitative scale $(0=$ definitely not prepared, $1=$ Not prepared, $2=$ Don't Know, $3=$ Prepared and 4= definitely prepared) was used to assess the level of preparedness. One can score a minimum of zero and a maximum of four for each item. The overall raw score of an individual can range from 0 to 52. The raw scores for all the items were converted to percentages. The scores less than or equal to $49 \%$ were considered low, the scores between $50 \%$ to $70 \%$ were considered as average and scores above $71 \%$ were considered high with respect to level of preparedness for internship. The 14th and 15th questions were open ended; answers to which were collated to list additional topics for orientation program and other suggestions. Since the study involves program evaluation and no clinical interventions, the Institutional ethics committee exempted the protocol from review.

\section{RESULTS}

A total of 110 interns completed the pre and post test. Data analysis revealed that only $2 \%$ of the interns were highly prepared for hospital practice before the orientation program while the number increased to $78 \%$ after the program.

Figure 1 shows overall score and the level of preparedness of interns for hospital practice

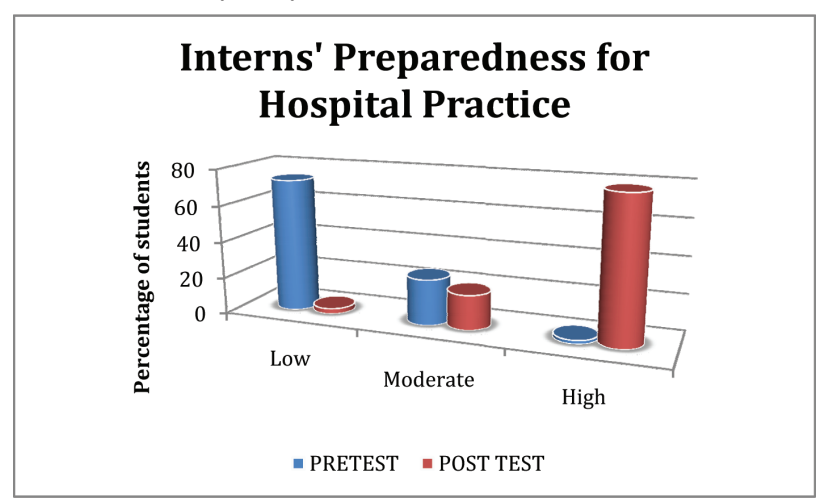

Figure 1: Overall pretest and posttest scores of the interns

Table 1 shows the interns' responses to internship preparedness survey questionnaire

\begin{tabular}{|c|c|c|c|c|c|c|c|c|c|c|c|}
\hline \multirow[t]{2}{*}{ No. } & \multirow[t]{2}{*}{ Session } & \multicolumn{2}{|c|}{$\begin{array}{c}\text { Definitely not } \\
\text { prepared }\end{array}$} & \multicolumn{2}{|c|}{ Not prepared } & \multicolumn{2}{|c|}{ Don't Know } & \multicolumn{2}{|c|}{ prepared } & \multicolumn{2}{|c|}{$\begin{array}{l}\text { Definitely } \\
\text { prepared }\end{array}$} \\
\hline & & $\begin{array}{l}\text { Pre } \\
\text { Test }\end{array}$ & $\begin{array}{l}\text { Pre } \\
\text { Test }\end{array}$ & $\begin{array}{l}\text { Pre } \\
\text { Test }\end{array}$ & $\begin{array}{l}\text { Pre } \\
\text { Test }\end{array}$ & $\begin{array}{l}\text { Pre } \\
\text { Test }\end{array}$ & $\begin{array}{l}\text { Pre } \\
\text { Test }\end{array}$ & $\begin{array}{l}\text { Pre } \\
\text { Test }\end{array}$ & $\begin{array}{l}\text { Pre } \\
\text { Test }\end{array}$ & $\begin{array}{l}\text { Pre } \\
\text { Test }\end{array}$ & $\begin{array}{l}\text { Pre } \\
\text { Test }\end{array}$ \\
\hline 1 & $\begin{array}{l}\text { Duties and } \\
\text { responsibilities of } \\
\text { Interns }\end{array}$ & $\begin{array}{c}8 \\
(7 \%)\end{array}$ & $\begin{array}{c}0 \\
(0 \%)\end{array}$ & $\begin{array}{c}27 \\
(24 \%)\end{array}$ & $\begin{array}{c}0 \\
(0 \%)\end{array}$ & $\begin{array}{c}41 \\
(37 \%)\end{array}$ & $\begin{array}{c}0 \\
(0 \%)\end{array}$ & $\begin{array}{c}32 \\
(29 \%)\end{array}$ & $\begin{array}{c}94 \\
(85 \%)\end{array}$ & $\begin{array}{c}2 \\
(2 \%)\end{array}$ & $\begin{array}{c}16 \\
(14 \%)\end{array}$ \\
\hline 2 & $\begin{array}{l}\text { Written and Verbal } \\
\text { Communication }\end{array}$ & $\begin{array}{c}3 \\
(2.7 \%)\end{array}$ & $\begin{array}{c}0 \\
(0 \%)\end{array}$ & $\begin{array}{c}28 \\
(255)\end{array}$ & $\begin{array}{c}1 \\
(1 \%)\end{array}$ & $\begin{array}{c}47 \\
(42 \%)\end{array}$ & $\begin{array}{c}1 \\
(1 \%)\end{array}$ & $\begin{array}{c}31 \\
(28 \%)\end{array}$ & $\begin{array}{c}89 \\
(80 \%)\end{array}$ & $\begin{array}{c}1 \\
(1 \%)\end{array}$ & $\begin{array}{c}19 \\
(17 \%)\end{array}$ \\
\hline
\end{tabular}




\begin{tabular}{|c|c|c|c|c|c|c|c|c|c|c|c|}
\hline 3 & $\begin{array}{l}\text { Medical Records } \\
\text { Documentation }\end{array}$ & $\begin{array}{c}11 \\
(10 \%)\end{array}$ & $\begin{array}{c}0 \\
(0 \%)\end{array}$ & $\begin{array}{c}24 \\
(22 \%)\end{array}$ & $\begin{array}{c}10 \\
(9 \%)\end{array}$ & $\begin{array}{c}60 \\
(54 \%)\end{array}$ & $\begin{array}{c}5 \\
(4 \%)\end{array}$ & $\begin{array}{c}15 \\
(14 \%)\end{array}$ & $\begin{array}{c}83 \\
(75 \%)\end{array}$ & $\begin{array}{c}0 \\
(0 \%)\end{array}$ & $\begin{array}{c}12 \\
(11 \%)\end{array}$ \\
\hline 4 & $\begin{array}{l}\text { Bedside Procedures } \\
\text { and Universal } \\
\text { Precautions }\end{array}$ & $\begin{array}{c}11 \\
(10 \%)\end{array}$ & $\begin{array}{c}0 \\
(0 \%)\end{array}$ & $\begin{array}{c}24 \\
(22 \%)\end{array}$ & $\begin{array}{c}10 \\
(9 \%)\end{array}$ & $\begin{array}{c}60 \\
(54 \%)\end{array}$ & $\begin{array}{c}5 \\
(4 \%)\end{array}$ & $\begin{array}{c}15 \\
(14 \%)\end{array}$ & $\begin{array}{c}83 \\
(75 \%)\end{array}$ & $\begin{array}{c}0 \\
(0 \%)\end{array}$ & $\begin{array}{c}12 \\
(11 \%)\end{array}$ \\
\hline 5 & $\begin{array}{l}\text { Medical Ethics and } \\
\text { Medicolegal issues in } \\
\text { patient care }\end{array}$ & $\begin{array}{l}10 \\
(9 \%)\end{array}$ & $\begin{array}{c}0 \\
(0 \%)\end{array}$ & $\begin{array}{c}34 \\
(31 \%)\end{array}$ & $\begin{array}{c}3 \\
(2.7 \%)\end{array}$ & & $\begin{array}{c}4 \\
(4 \%)\end{array}$ & $\begin{array}{c}20 \\
(18 \%)\end{array}$ & $\begin{array}{c}93 \\
(84 \%)\end{array}$ & $\begin{array}{c}1 \\
(1 \%)\end{array}$ & $\begin{array}{c}10 \\
(9 \%)\end{array}$ \\
\hline 6 & $\begin{array}{l}\text { Handling Peadiatric } \\
\text { cases }\end{array}$ & $\begin{array}{c}18 \\
(16 \%)\end{array}$ & $\begin{array}{c}0 \\
(0 \%)\end{array}$ & $\begin{array}{c}39 \\
(35 \%)\end{array}$ & $\begin{array}{c}15 \\
(14 \%)\end{array}$ & $\begin{array}{c}47 \\
(43 \%)\end{array}$ & $\begin{array}{c}29 \\
(26 \%)\end{array}$ & $\begin{array}{c}6 \\
(5 \%)\end{array}$ & $\begin{array}{c}65 \\
(59 \%)\end{array}$ & $\begin{array}{c}0 \\
(0 \%)\end{array}$ & $\begin{array}{c}1 \\
(1 \%)\end{array}$ \\
\hline 7 & $\begin{array}{l}\text { Handling of Blood } \\
\text { and Blood products }\end{array}$ & $\begin{array}{c}12 \\
(11 \%)\end{array}$ & $\begin{array}{c}0 \\
(0 \%)\end{array}$ & $\begin{array}{c}44 \\
(40 \%)\end{array}$ & $\begin{array}{c}7 \\
(6 \%)\end{array}$ & $\begin{array}{c}38 \\
(34 \%)\end{array}$ & $\begin{array}{c}6 \\
(5 \%)\end{array}$ & $\begin{array}{c}15 \\
(14 \%)\end{array}$ & $\begin{array}{c}87 \\
(79 \%)\end{array}$ & $\begin{array}{c}1 \\
(1 \%)\end{array}$ & $\begin{array}{c}10 \\
(9 \%)\end{array}$ \\
\hline 8 & $\begin{array}{l}\text { Post Exposure } \\
\text { prophylaxis }\end{array}$ & $\begin{array}{c}9 \\
(8 \%)\end{array}$ & $\begin{array}{c}0 \\
(0 \%)\end{array}$ & $\begin{array}{c}44 \\
(40 \%)\end{array}$ & $\begin{array}{c}5 \\
(4 \%)\end{array}$ & $\begin{array}{c}42 \\
(38 \%)\end{array}$ & $\begin{array}{c}6 \\
(5 \%)\end{array}$ & $\begin{array}{c}13 \\
(12 \%)\end{array}$ & $\begin{array}{c}82 \\
(74 \%)\end{array}$ & $\begin{array}{c}2 \\
(2 \%)\end{array}$ & $\begin{array}{c}17 \\
(15 \%)\end{array}$ \\
\hline 9 & $\begin{array}{l}\text { Biomedical Waste } \\
\text { Management, } \\
\text { RHTC,UHTC }\end{array}$ & $\begin{array}{c}9 \\
(8 \%)\end{array}$ & $\begin{array}{c}0 \\
(0 \%)\end{array}$ & $\begin{array}{c}39 \\
(35 \%)\end{array}$ & $\begin{array}{c}1 \\
(1 \%)\end{array}$ & $\begin{array}{c}39 \\
(35 \%)\end{array}$ & $\begin{array}{c}3 \\
(3 \%)\end{array}$ & $\begin{array}{c}22 \\
(20 \%)\end{array}$ & $\begin{array}{c}81 \\
(74 \%)\end{array}$ & $\begin{array}{c}1 \\
(1 \%)\end{array}$ & $\begin{array}{c}25 \\
(23 \%)\end{array}$ \\
\hline 10 & $\begin{array}{l}\text { Handling Medical } \\
\text { Emergencies }\end{array}$ & $\begin{array}{c}16 \\
(14 \%)\end{array}$ & $\begin{array}{c}0 \\
(0 \%)\end{array}$ & $\begin{array}{c}35 \\
(32 \%)\end{array}$ & $\begin{array}{c}11 \\
(10 \%)\end{array}$ & $\begin{array}{c}51 \\
(46 \%)\end{array}$ & $\begin{array}{c}11 \\
(10 \%)\end{array}$ & $\begin{array}{c}6 \\
(5 \%)\end{array}$ & $\begin{array}{c}78 \\
(71 \%)\end{array}$ & $\begin{array}{c}2 \\
(2 \%)\end{array}$ & $\begin{array}{c}5 \\
(4 \%)\end{array}$ \\
\hline 11 & $\begin{array}{l}\text { Optimal Use of Lab } \\
\text { services }\end{array}$ & $\begin{array}{l}10 \\
(9 \%)\end{array}$ & $\begin{array}{c}0 \\
(0 \%)\end{array}$ & $\begin{array}{c}28 \\
(25 \%)\end{array}$ & $\begin{array}{c}4 \\
(4 \%)\end{array}$ & $\begin{array}{c}52 \\
(47 \%)\end{array}$ & $\begin{array}{c}9 \\
(8 \%)\end{array}$ & $\begin{array}{c}21 \\
(19 \%)\end{array}$ & $\begin{array}{c}82 \\
(75 \%)\end{array}$ & $\begin{array}{c}0 \\
(0 \%)\end{array}$ & $\begin{array}{c}15 \\
(14 \%)\end{array}$ \\
\hline 12 & $\begin{array}{l}\text { Handling trauma } \\
\text { cases }\end{array}$ & $\begin{array}{c}14 \\
(13 \%)\end{array}$ & $\begin{array}{c}0 \\
(0 \%)\end{array}$ & $\begin{array}{c}40 \\
(36 \%)\end{array}$ & $\begin{array}{c}9 \\
(8 \%)\end{array}$ & $\begin{array}{c}48 \\
(44 \%)\end{array}$ & $\begin{array}{c}10 \\
(9 \%)\end{array}$ & $\begin{array}{c}7 \\
(6 \%)\end{array}$ & $\begin{array}{c}86 \\
(78 \%)\end{array}$ & $\begin{array}{c}1 \\
(1 \%)\end{array}$ & $\begin{array}{c}5 \\
(4 \%)\end{array}$ \\
\hline 13 & $\begin{array}{l}\text { Preoperative and } \\
\text { Post operative care } \\
\text { of patients and OT } \\
\text { etiquette }\end{array}$ & $\begin{array}{c}6 \\
(5 \%)\end{array}$ & $\begin{array}{c}0 \\
(0 \%)\end{array}$ & $\begin{array}{c}46 \\
(42 \%)\end{array}$ & $\begin{array}{c}4 \\
(4 \%)\end{array}$ & $\begin{array}{c}37 \\
(34 \%)\end{array}$ & $\begin{array}{c}2 \\
(2 \%)\end{array}$ & $\begin{array}{c}18 \\
(16 \%)\end{array}$ & $\begin{array}{c}87 \\
(79 \%)\end{array}$ & $\begin{array}{c}3 \\
(3 \%)\end{array}$ & $\begin{array}{c}17 \\
(15 \%)\end{array}$ \\
\hline
\end{tabular}

The interns expressed their desire to learn new topics like basic first aid to minor injuries and steps to be taken, management of trauma cases and Road-Traffic Accidents (RTAs) and in detail on handling of medical emergencies

Suggestion given by the interns was that there should be more practical demonstrations of skills and more time should be given for hands on training on skills lab.

\section{DISCUSSION}

The Indian medical curriculum ensures that students amass vast amount of knowledge with solid ground in science. But this does not formally translate into providing them with practical skills, work related skills and effective communication skills to become an effective doctor. Internship is the phase of conduit between the graduation and early working life during which the students are expected to acquire and demonstrate all the necessary skills. A two day internship orientation program is conducted in most of the medical colleges in India at the beginning of the internship to ensure their smooth passage into the working life.

The results of the present study demonstrate that there is an overall improvement in the preparedness of Interns for internship after the orientation program. The results are in agreement with the study conducted at JIPMER, Puducherry in $2017^{3}$ and at AlIMS, New Delhi in 2008. ${ }^{4}$

The study is limited by the fact that it represents data of only one women's medical college. Similar studies are warranted in other colleges for more decisive information.

To conclude, Internship orientation program proved to be valuablein allaying the fears and boost the confidence of Interns for hospital practice. 


\section{REFERENCES}

1. Medical Council of India, New Delhi. Regulations on Graduate Medical Education., 1997. https:// www.mciindia.org/CMS/rules-regulations/graduatemedical-education-regulations-1997 (accessed on 6th September 2019)

2. Ashish G, Venkat R, Kumar A, Adkoli BV, Rita S. Structured internship orientation programme for undergraduate students: Easy transition to clinical work. Natl Med J India 2010;23:160-2

3. Zayapragassarazan Z. Preparedness of Interns for Hospital Practice before and after an Orientation Programme. Asian Journal of Education and Training. 2017.3(2): 105109.

4. Ashish G, Venkat R, Kumar A, Adkoli BV, Rita S. Structured internship orientation programme for undergraduate students: Easy transition to clinical work. Natl Med J India 2010;23:160-2

How to cite this article : Padmavathi V, Tekulapally K. Preparedness for Internship: A Survey of New Interns at a Tertiary Care Hospital, Telangana Perspectives in Medical Research 2021; 9 (2):24-27

DOI: 10.47799/pimr.0902.06

Sources of Support: Nil, Conflict of interest: None declared 